\title{
PENGARUH BAHAN PENGENCER SARI KACANG KEDELAI (Glycine max) TERHADAP VIABILITAS DAN NEKROSIS SPERMATOZOA DOMBA SAPUDI
}

\section{THE EFFECT OF SOYA BEAN(Glycine max) EXTRACTIN SPERM DILUTER TO THE SPERM VIABILITY AND NECROSIS IN SAPUDI RAM}

\author{
Kicky Hanis Immelda ${ }^{1)}$, *Suherni Susilowati ${ }^{2)}$, Ira Sari Yudaniayanti ${ }^{3)}$ \\ ${ }^{1)}$ Student, ${ }^{2)}$ Veterinary Reproduction Department, ${ }^{3)}$ Klinik Department \\ Faculty Veterinary Medicine, Universitas Airlangga \\ *Corresponding author: suhernifkhunair@gmail.com; parkbogummy14@ gmail.com
}

\begin{abstract}
The purpose of study was to find out the effect of different concentrations of soya bean extractin sperm diluter, stored at $5^{\circ} \mathrm{C}$ toward sperm viability and necrosis. The semen was divided into four groups : P0: $0.1 \mathrm{ml}$ sapudi ram $+1 \mathrm{ml}$ of diluent yolk citrate, P1: sapudi ram $0.1 \mathrm{ml}+1 \mathrm{ml}$ diluent soybeans extract konsentration 5\%, P2: $0.1 \mathrm{ml}$ sapudi ram $+1 \mathrm{ml}$ diluent soybeans extract konsentration 10\%, P3: $0.1 \mathrm{ml}$ sheep semen $+1 \mathrm{ml}$ diluent soybeans konsentration $15 \%$. The result showed that the dose of soya bean extract diluter konsentration of $15 \%$ could increase the viability percentage and could decrease the necrosis percentage of sperm.
\end{abstract}

Key words : egg yolk citrate, soya bean extract, sapudi ram, sperm quality.

\section{Pendahuluan}

Ternak domba (Genus ovis) merupakan jenis ternak yang sudah lama dikenal masyarakat Indonesia. Salah satu keunggulan ternak domba adalah mudah dipelihara, produktivitas cepat, dan harganya relatif terjangkau sehingga berpotensi untuk dikembangkan. Pengembangan dapat melalui peningkatan kualitas pejantan unggul untuk pembibitan. Pejantan unggul yang sehat fisik dan reproduksi akan menghasilkan spermatozoa yang baik untuk menghasilkan anak yang baik (Afiati dkk., 2013).

Salah satu cara untuk meningkatkan sifat genetik ternak domba dengan melaksanakan atau melakukan cara Inseminasi Buatan (IB).Keberhasilan pelaksanaan Inseminasi Buatan (IB) ditentukan salah satunya oleh kualitas semen yang digunakan, maka sebelum digunakan untuk inseminasi semen perlu diencerkan terlebih dahulu. Semen yang tidak diencerkan akan sukar mempertahankan hidupnya lebih dari $24 \mathrm{jam}$, walaupun disimpan dalam suhu $0^{\circ} \mathrm{C}$ sampai $5^{\circ} \mathrm{C}$ (Partodiharjo, 1992). Dalam proses pembuatan semen beku, nutrisi yang terdapat pada pengencer yang digunakan sangat berperan penting dalam melindungi spermatozoa. Oleh sebab itu, pengencer harus mampu menyediakan bahan makanan sebagai sumber energi bagi spermatozoa, melindungi spermatozoa dari kejutan dingin (cold shock), berfungsi sebagai buffer atau penyangga untuk mencegah perubahan $\mathrm{pH}$, dan lain sebagainya (Arifiantini dan Yusuf, 2004).

Bahan pengencer semen harus mempunyai kriteria tidak beracun, berenergi, mampu mempertahankan kualitas semen, bersifat sebagai pelindung, buffer, antibiotika, isotonis, keseimbangan mineral dan krioprotektan yang baik untuk kehidupan spermatozoa, dan bahan anti cold shock (Hardijanto dkk. 2010).

Kedelai (Glycine max L. Merr) merupakan salah satu komoditas tanaman pangan nabati yang cukup diminati oleh masyarakat. Alasan kedelai diminati antara lain karena dalam biji kedelai terkandung zat gizi yang tinggi terutama protein dengan kualitas yang mendekati daging hewan. Di antara kacang-kacangan, kadar protein kedelai memang yang paling tinggi (Rukmana dan Yuniarsih, 1996). 
Kandungan sari kedelai dalam pengencer seperti lesitin terbukti dapat melindungi dan menekan angka abnormallitas spermatozoa selama masa penyimpanan mengurangi kontaminasi mikroorganisme pada spermatozoa. Sari kedelai juga diketahui memiliki kecenderungan terkontaminasi bakteri lebih kecil daripada kuning telur dan air susu sapi sehingga menekan angka abnormalitas lebih kecil. Menurut penelitian Bousseau dkk. (1998) bahwa tidak ditemukannya mikroorganisme yang membahayakan bagi spermatozoa pada pengencer yang mengandung lesitin. Hal ini didukung oleh penelitian Aries dkk.(2003) bahwa lesitin dari kacang kedelai memiliki bahan yang mirip dengan lesitin dari kuning telur, berperan melindungi integritas selubung protein sel spermatozoa sehingga lebih tahan terhadap pengaruh cold shock. Aku dkk. (2007) menambahkan bahwa penggunaan lesitin nabati mengurangi efek cekaman dingin serta lipoprotein dan lesitin nabati seperti kacang kedelai, sedangkan kuning telur dan susu terkontaminasi oleh bakteri dan mycoplasma.

Kualitas spermatozoa yang baik dipengaruhi oleh motilitas dan viabilitas, karena sangat berpengaruh bagi spermatozoa untuk mencapai tempat pembuahan (Hafez, 2000). Kerusakan selama pembekuan umumnya terjadi pada membran plasma maupun inti spermatozoa atau yang disebut dengan nekrosis, kerusakan pada inti spermatozoa dapat menyebabkan mutasi gen (Edinger dan Thompson, 2004).

Berdasarkan uraian diatas maka peneliti ingin meneliti apakah terdapat pengaruh bahan pengencer sari kacang kedelai terhadap viabilitas dan nekrosis spermatozoa domba.

\section{Materi Dan Metode}

\section{Waktu dan Tempat Penelitian}

Penelitian dilakukan di kandang hewan coba Fakultas Kedokteran Hewan Unair untuk menampung semen dan Laboratorium Inseminasi Buatan (IB) Departemen Reproduksi Fakultas Kedokteran Hewan Universitas Airlangga.

\section{Metode Penelitian Penampungan Semen Domba Sapudi}

Semen yang di tampung berasal dari domba Sapudi yang sehat dan tidak memiliki kecacatan serta kondisi alat reproduksinya baik. Penampungan dilakukan pada pagi hari dengan menggunakan vagina buatan kemudian, semen yang diperoleh diperiksa secara makroskopis dan mikroskopis. Pemeriksaan makroskopis meliputi volume, bau, warna, konsistensi dan $\mathrm{pH}$ serta pemeriksaan mikroskopis meliputi gerakan massa, gerakan individu, viabilitas, konsentrasi, dan uji resistensi.

\section{Pembuatan Pengencer Kuning Telur Si- trat}

Pengencer kuning telur sitrat dalam penelitian ini sebagai kontrol. Kuning telur yang akan dipakai berasal dari kuning telur ayam ras. Kuning telur sitrat merupakan pengencer kuning telur yang ditambahkan larutan natrium sitrat. Larutan tersebut berasal dari natrium sitrat dan aquades yang telah dihomogenkan.

\section{Pembuatan Pengencer Sari Kacang Ke- delai}

Cara pembuatan sari kacang kedelai sebagai berikut:

Kacang kedelai yang akan di ambil sarinya dipisah dari kulitnya dan ditimbang dengan 3 macam perbandingan yaitu 12,5 gram, 25 gram, dan 37,5 gram. Kemudian direndam dengan air panas selama 15 menit dan tiriskan untuk memudahkan proses penggilingan. Kacang kedelai yang digiling kemudian di ditambahkan aquadest $250 \mathrm{ml}$. Setelah halus kemudian kacang kedelai disaring dan ditambahkan natrium sitrat dengan perbandingan 1:1 lalu diperiksa pHnya ( $\mathrm{pH}$ 7) .Lalu tambahkan antibiotika penicilin 1000 IU dan streptomycin $1 \mathrm{mg}$ ditambahkan kedalam setiap milliliter pengencer kacang kedelai dan di aduk sampai homogen. Selanjutnya diberi perlakuan yaitu P0, P1, P2 dan P3.

\section{Prosedur Pengenceran Semen}

Sampel semen segar di ambil $0,1 \mathrm{ml}$ dan dimasukkan ke dalam tabung reaksi yang masing- masing telah diberi label kemudian di encerkan dengan kuning telur sitrat dan sari kacang kedelai berbagai konsentrasi dan perbandingan 1:10 adalah: 
-P0 : 0,1 ml semen domba sapudi $+1 \mathrm{ml}$ pengencer kuning telur sitrat

-P1 : 0,1 ml semen domba sapudi $+1 \mathrm{ml}$ bahan pengencer sari kacang kedelai dengan konsentrasi 5\%

-P2 : 0,1 ml semen domba sapudi $+1 \mathrm{ml}$ bahan pengencer sari kacang kedelai dengan konsentrasi $10 \%$

-P3 : 0,1 ml semen domba sapudi $+1 \mathrm{ml}$ bahan pengencer sari kacang kedelai dengan konsentrasi $15 \%$

Penentuan dosis dikutip dari skripsi Danik (2013).

Campuran semen dan pengencer di simpan pada suhu $5^{\circ} \mathrm{C}$ di dalam lemari pendingin dan dilakukan pemeriksaan 24jam terhadap viabilitas dan nekrosis spermatozoa .

\section{Pemeriksaan Viabilitas}

Pemeriksaan persentase spermatozoa hidup dan mati menggunakan zat eosin negrosin. Spermatozoa yang tidak menyerap zat warna dinyatakan spermatozoa hidup. Sebaliknya, spermatozoa yang menyerap zat warna dinyatakan spermatozoa mati. Spermatozoa hidup memiliki membran yang baik sehingga zat warna akan kesulitan menembus membran spermatozoa, hal tersebut membuat spermatozoa tetap bewarna jenih (Susilowati dkk., 2010).

\section{Pemeriksaan Nekrosis}

Pemeriksaan nekrosis spermatozoa menggunakan pewarnaan Hematoxylin Eosin. Hematoxylin bekerja sebagai pewarna basa artinya zat ini mewarnai unsur basofilik. Hematoxylin memulas inti (nucleus) menjadi berwarna biru. Eosin bersifat asam sehingga memulas sitoplasma sel menjadi berwarna merah. Pewarnaan Hematoxylin Eosin merupakan jenis pewarnaan rutin yang paling umum digunakan (Damayanti dkk., 2011. Pengamatan dilakukan di bawah mikroskop dengan pembesaran 400 kali dan dihitung persentase spermatozoa yang mengalami nekrosis. Sel yang mengalami nekrosis dapat dilihat dari keadaan nukleus atau inti sel. Inti sel pada sel yang mengalami nekrosis dapat berupa piknosis (inti sel memadat), karioreksis (inti terkoagulasikan), dan kariolisis (inti sel memudar atau mengalami lisis).

\section{Hasil dan Pembahasan}

Pada penelitian ini dibutuhkan semen segar domba Sapudi. Semen segar dombaSapudi yang di ambil semennnya diperiksa terlebih dahulu secara macroskopis dan mikroskopis. Hasil pemeriksaan semen segar domba Sapudi dapat dilihat pada tabel berikut.

\section{Pemeriksaan Viabilitas Spermatozoa Domba Sapudi}

Pemeriksaan daya hidup (viabilitas) spermatozoa dilakukan menggunakan preparat pewarnaan eosin-negrosin dengan menggunakan mikroskop cahaya perbesaran 400x (objek $\mathrm{x}$ okuler $=40 \mathrm{x}$ 10). Spermatozoa yang hidup tidak akan terwarnai oleh zat warna, sedangkan spermatozoa yang mati akan terwarnai merah keunguan.

Berdasarkan Analisis of Variance (ANOVA) satu arah yang dilanjutkan dengan uji jarak berganda Duncan terhadap daya hidup (viabilitas) spermatozoa menunjukkan P0 tidak berbeda nyata dengan $\mathrm{P} 2$ tetapi berbeda nyata $(\mathrm{P}<0,05)$ dengan kelompok perlakuan P1 dan P3. Rerata dan standar devisiasi persentase spermatozoa domba Sapudi tersaji dalam tabel 2.

Hasil uji ANOVA terhadap persentase nekrosis spermatozoa domba Sapudi setelah perlakuan menunjukkan $\mathrm{P} 0$ berbeda nyata $(\mathrm{P}<0,05)$ dengan $\mathrm{P} 3$, tetapi tidak berbeda nyata $(\mathrm{P}>0,05)$ dengan $\mathrm{P} 1$ dan $\mathrm{P} 2$. Pada pemeriksaan nekrosis menunjukkan P3 berbeda nyata dengan P0, P1, dan P2. Berdasarkan tabel presentase nekrosis spermatozoa domba Sapudi dapat di lihat pada Gambar 2.

Evaluasi semen domba segar perlu dilakukan untuk mengetahui kualitas semen yang akan digunakan dalam program Inseminasi Buatan (IB). Pemeriksaan kualitas semen segar juga dilakukan karena dapat digunakan untuk menentukan kadar pengencer yang dibutuhkan. Pemeriksaan semen domba segar digolongkan dalam 2(dua) kelompok, yakni makroskopis dan mikroskopis. Dalam penelitian ini kualitas semen domba segar yang dievaluasi secara makroskopis meliputi bau, pH, warna, konsistensi dan volume. Sedangkan pemeriksaan secara mikroskopis meliputi motilitas, gerak 
Penentuan presentase spermatozoa hidup dapat menggunakan rumus :

$$
\begin{aligned}
& \% \text { viabilitas spermatozoa }=\frac{\text { Jumlah spermatozoa hidup }}{\text { total spermatozoa yang diamati }} \times 100 \% \\
& \text { Total spermatozoa hidup yang di amatiadalah } 100 \text { sel spermatozoa }
\end{aligned}
$$

Persentase nekrosis spermatozoa dihitung menggunakan rumus:

$$
\text { Persentase Nekrosis }=\frac{\text { Jumlah spermatozoa yang nekrosis }}{\text { total spermatozoa hidup }} \text { X 100\% }
$$

Tabel 1. Hasil pemeriksaan makroskopis dan mikroskopis spermatozoa domba Sapudi sebelum perlakuan

\begin{tabular}{cc}
\hline Parameter & Ukuran \\
\hline Volume $(\mathrm{ml})$ & 0,96 \\
Bau & Khas \\
Warna & Krem \\
pH & $6-7$ \\
Konsistensi & Kental \\
Konsentrasi (Juta/ml) & 2780 \\
Spermatozoa Hidup $(\%)$ & 92,2 \\
Spermatozoa Abnormal $(\%)$ & 3,2 \\
Gerak Individu & Progresif \\
Gerak Massa & +++ \\
\hline
\end{tabular}

Keterangan : $\mathrm{pH}=$ power of Hydrogen

$+++=$ Gelombang kecil sampai besar yang tebal dangelombang dalam jumlah banyak dan cepat.

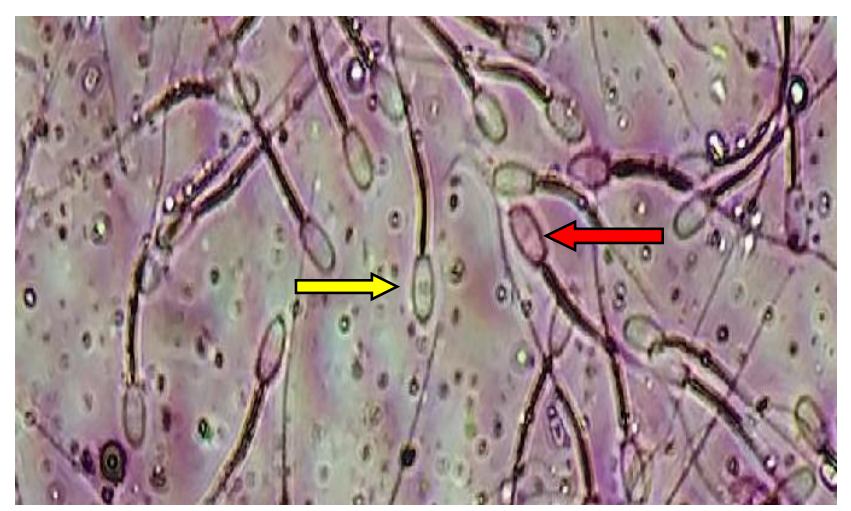

Gambar 1. Pada keterangan gambar di atas menunjukkan spermatozoa yang hidup ditandai dengan panah berwarna kuning, dan spermatozoa yang mati ditandai dengan panah berwarna merah.

massa, konsentrasi spermatozoa dan persentase spermatozoa hidup (Rizal dan Herdis, 2008).

Pengaruh pemberian bahan sari kacang kedelai terhadap spermatozoa domba. Sapudi dapat meningkatkan viabiltas karena menurut Toelihere (1985) bahan pelindung spermatozoa selama penyimpanan dalam suhu dingin adalah lesitin. Sumber lesitin yang utama telah lama di gunakan adalah kuning telur sebab dapat mempertahankan kualitas semen mamalia serta mencegah efek dari cold shock dan terjadinya resiko kontaminasi 
mikroorganisme yang membahayakan spermatozoa dan saluran reproduksi betina.

dingkan berbagai jenis pengencer dengan Namun Bousseau et al. (1998) membansumber lipoprotein dan lesitin

Tabel 2. Rerata dan Standart Devisiasi Persentase Viabilitas Spermatozoa Domba Sapudi Setelah Perlakuan

\begin{tabular}{ccc}
\hline Perlakuan & Ulangan $(\mathbf{n})$ & Viabilitas Spermatozoa \\
\hline P0 & 6 & $80,0^{\mathrm{b}} \pm 2,19$ \\
P1 & 6 & $72,8^{\mathrm{a}} \pm 4,83$ \\
P2 & 6 & $80,1^{\mathrm{b}} \pm 2,40$ \\
P3 & 6 & $84,3^{\mathrm{c}} \pm 1,96$ \\
\hline
\end{tabular}

Superskripsi yang berbeda pada kolom yang sama menunjukkan perbedaan yang nyata $(\mathrm{p}<0,05)$

Keterangan : $\mathrm{P} 0=0,1 \mathrm{ml}$ semen domba $+1 \mathrm{ml}$ pengencer kuning telur sitrat

$\mathrm{P} 1=0,1 \mathrm{ml}$ semen domba $+1 \mathrm{ml}$ pengencer sari kacang kedelai konsentrasi $5 \%$

$\mathrm{P} 2=0,1 \mathrm{ml}$ semen domba $+1 \mathrm{ml}$ pengencer sari kacang kedelai konsentrasi $10 \%$

$\mathrm{P} 3=0,1 \mathrm{ml}$ semen domba $+1 \mathrm{ml}$ pengencer sari kacang kedelai konsentrasi $15 \%$

\section{Viabilitas}

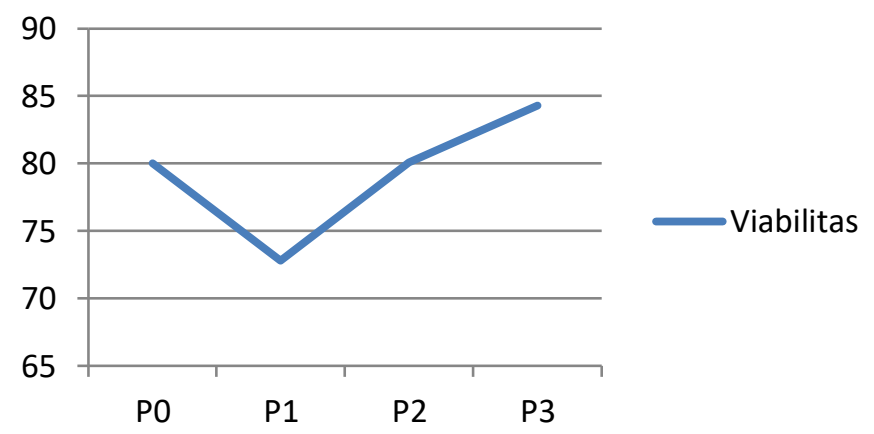

Gambar 2. Grafik Rata-rata Persentase Viabilitas Domba Sapudi

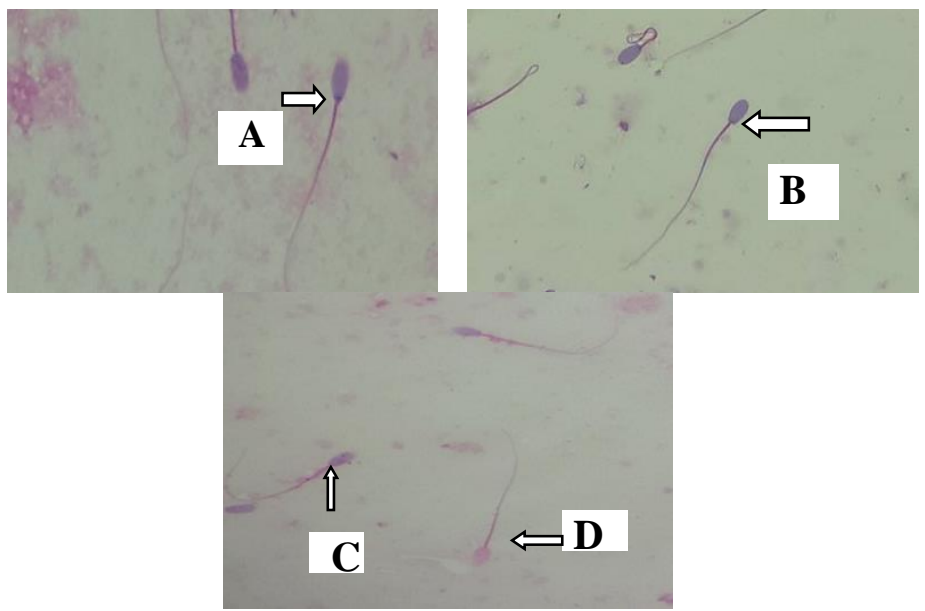

Gambar 3. Pemeriksaan nekrosis spermatozoa domba Sapudi dengan pewarnaan HE (Hematoxylin Eosin), perbesaran 400x.

Keterangan: A : Spermatozoa yang mengalami nekrosis dengan inti piknotis

B : Spermatozoa yang tidak mengalami nekrosis

C : Spermatozoa yang mengalami nekrosis dengan inti karioreksis

D : Spermatozoa yang mengalami nekrosis dengan inti kariolisis 
Tabel 3. Rerata dan Standart Devisiasi Presentase Nekrosis Spermatozoa Domba Sapudi setelah perlakuan

\begin{tabular}{lll}
\hline Perlakuan & Ulangan & Nekrosis Spermatozoa \\
\hline P0 & 6 & $5,16^{\mathrm{b}} \pm 1,94$ \\
P1 & 6 & $5,16^{\mathrm{b}} \pm 1,60$ \\
P2 & 6 & $4,5^{\mathrm{b}} \pm 0,83$ \\
P3 & 6 & $2,33^{\mathrm{a}} \pm 0,81$ \\
\hline
\end{tabular}

Superskrip pada kolom yang sama dengan notasi yang berbeda menunjukkan perbedaan yang nyata $(\mathrm{P}<0,05)$

\section{Nekrosis}

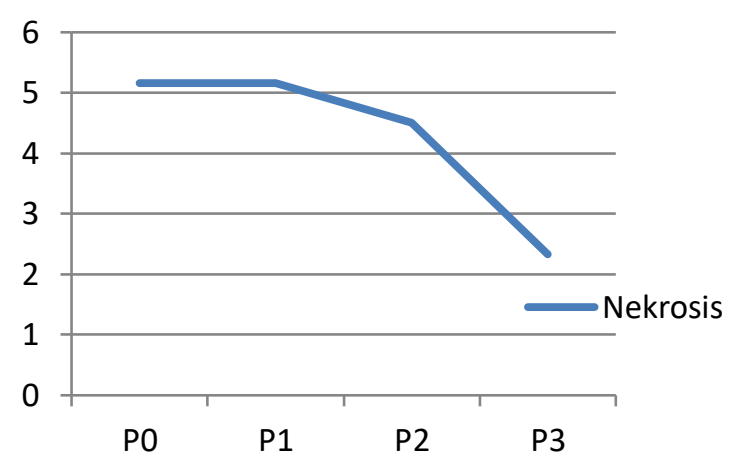

Gambar 4. Grafik Rata-rata Persentase Nekrosis Domba Sapudi

dalam kuning telur masih mengandung bakteri dan mycoplasma sedangkan yang menggunakan lipoprotein dan lesitin nabati yang terdapat pada sari kacang kedelai tidak di temukan bahaya mikroorganisme yang membahayakan spermatozoa.

Berdasarkan hasil pemeriksaan presentase pengaruh bahan pengencer sari kacang kedelai pada semen domba sapudi terhadap viabilitas spermatozoa menunjukkan hasil terbaik pada kelompok P3 dengan rata-rata dan standard deviasi yaitu menunjukkan 84,3 di banding dengan kelompok perlakuan P0, P1 dan P2. Hal ini menunjukkan bahwa pengaruh bahan pengencer sari kacang kedelai dengan konsentrasi $15 \% \quad[0,1$ semen domba sapudi+1 $1 \mathrm{ml}$ bahan pengencer kacang kedelai(37,5)gram $+250 \mathrm{ml}$ aquadest)] dapat meningkatkan kualitas viabilitas domba sapudi.

Hasil penelitian Aku (2005) menyatakan bahwa lesitin kacang kedelai mengandung protein, karbohidrat (fruktosa,glukosa, manosa, dan maltotriosa), mineral(natrium, kalsium, kalium, magnesium, klorida, fosfor, dan mangan), asam sitrat, gliserol, lemak, lesitin, dan gliserilfosforil kolin (GPC).

\section{Nekrosis Spermatozoa Domba Sapudi}

Nekrosis atau kematian sel sebagai akibat adanya kerusakan sel akut atau trauma (misal: kekurangan oksigen, perubahan suhu yang ekstrim, cedera mekanis). Menurut Feitosa et al. (2008) nekrosis ditandai sebagai akibat cidera sel yang menyebabkan volume sel dan pecahnya membran. Kerusakan pada membran plasma spermatozoa dapat menginduksi terjadinya nekrosis spermatozoa.

Persentase nekrosis spermatozoa diuji menggunakan pewarnaan HE (Hematoxylin Eosin). Prinsip pada pewarnaan HE yaitu hematoxylin bersifat basa yang mewarnai unsur basofilik, memulas inti (nucleus) menjadi warna biru. Eosin bersifat asam sehingga memulas sitoplasma sel menjadi warna merah (Damayanti dkk., 2011). Secara mikroskopis, nekrosis menyebabkan berbagai macam tahapan perubahan morfologi pada inti, yaitu terlihat memadat bewarna gelap (piknotis), 
kemudian inti terfragmen-fragmen menjadi pecahan kecil-kecil (karyoreksis), dan terakhir inti menjadi memudar dan pucat tidak terwarnai (karyolisis) (Soemirat, 2005).

Hasil pemeriksaan presentase nekrosis spermatozoa pada domba Sapudi, angka rata-rata dan standard deviasi pada kelompok perlakuan P3 yaitu menunjukkan 2,33 . Pemberian pengaruh bahan pengencer sari kacang kedelai pada konsentrasi $15 \%$ (37,5 gram kacang kedelai +250 aquadest) pada P3 menghasilkan nekrosis terendah dan berbeda nyata dengan $\mathrm{P} 0$, P1, dan P2. Perlakuan kelompok P3 terbukti menurunkan jumlah nekrosis spermatozoa domba, karena kacang kedelai memiliki kandungan gizi yang baik dengan kandungan protein 11 kali lebih tinggi sehingga sangat berguna bagi spermatozoa. (Rizal dkk., 2003).

\section{Kesimpulan}

Pemberian bahan pengencer sari kacang kedelai sitrat dengan konsentrasi tertinggi yaitu $15 \%$ pada penelitian ini dapat meningkatkan viabilitas dan menurunkan nekrosis pada spermatozoa domba sa pudi.

\section{Saran}

Saran yang dapat di ambil dari penelitian ini adalah bahan pengencer sari kacang kedelai sirat dapat digunakan sebagai bahan pengencer semen domba dan disarankan untuk diadakan penelitian lebih lanjut untuk mengetahui bahan pengencer sari kacang kedelai sitrat pada semen beku domba sapudi.

\section{Daftar Pustaka}

Afiati F, Herdis,dan S Said. 2013. Pembibitan Ternak dengan Inseminasi Buatan. Penebar Swadaya. Jakarta.

Arifiantini RI. dan Yusuf TL. 2004. Keberhasilan penggunaan tiga pengencer dalamdua jenis kemasan pada proses pembekuan semen sapi Frisien Holstein.Fakultas Kedokteran Hewan, Institut Pertanian Bogor. Bogor.

Bousseau, S., J.P. Brillar, B.M. Le Guine, B. Guine, A. Camus and M. Lechat. 1998. Comparasion Bacteriological Qualities of Various Egg Yolk Sources and the In Vitro and
In Vivo Fertilizing Potential of Bovine in Egg Yolk and Lecitinbased Diluents. Theriogenology. 50: 699-706.

Damayanti, A., F. Lupita, Kurniawan, Regina, dan Yenny. 2011. Pewarnaan Histologi. Akademi Analis Kesehatan Nasional. Surakarta.

Edinger ,A. L. and Thompson CB. 2004. Death by Design : Apoptosis, Nekrosis and Authophagy. Current Opinion in Cell Biology. 16: 663669.

Hafez, E. S. E. 2000. Semen Evaluation. In: Reproduction In Farm Animals. $7^{\text {th }}$ Edition. Lippincott Wiliams and Wilkins. Maryland. USA.

Hardijanto, S. Susilowati, T. Sardjito, T. Hernawati, danT. W. Suprayogi. 2010. Buku Ajar Inseminasi Buatan. Airlangga University Pres. Surabaya. 15-38, 82-91.

Margaret Danik, M. 2013. Pengaruh Berbagai Presentase Pengencer Ka-cang Tanah Terhadap Motilitas dan Viabilitas Spermatozoa

Partodiharjo, S. 1992. Ilmu Reproduksi Hewan. Mutiara Sumber Widya. Jakarta Pusat. 545-553.

Rizal, M., M.R. Toelihere, T.L. Yusuf, B Purwantara dan P. Situmorang . 2003. Kriopreservasi semen Domba Garut dalam pengencer Tris dan Konsentrasi Laktosa yang berbeda. Media Kedokteran Hewan. 19(2): 79-83.

Rizal, M., dan Herdis. 2008. Inseminasi Buatan pada Domba. Penerbit Penebar Swadaya. Jakarta.

Rukmana, R. dan YYuniarsih., 1996. Kedelai Budidaya dan pasca panen. Kanisius, Yogyakarta.

Soemirat, J. 2005. Toksikologi Lingkungan. Gajah Mada University Press. Yogyakarta.

Susilowati S, Hardijanto, T. W. Suprayogi, T. Sardjito, T. Hernawati. 2010. Penuntun Praktikum Inseminasi Buatan. Airlangga University Press. Surabaya.

Toelihere, M.R. 1985. Fisiologi Reproduksi pada Ternak. Penerbit Angkasa Bandung. 93-100, 116-128. 